IZA DP No. 9447

Gender and Corruption: A Reassessment

Julia Debski

Michael Jetter

October 2015

Forschungsinstitut

zur Zukunft der Arbeit

Institute for the Study

of Labor 


\title{
Gender and Corruption: A Reassessment
}

\author{
Julia Debski \\ University of Bayreuth
}

Michael Jetter

University of Western Australia

and IZA

\section{Discussion Paper No. 9447 \\ October 2015}

\author{
IZA \\ P.O. Box 7240 \\ 53072 Bonn \\ Germany \\ Phone: +49-228-3894-0 \\ Fax: +49-228-3894-180 \\ E-mail: iza@iza.org
}

\begin{abstract}
Any opinions expressed here are those of the author(s) and not those of IZA. Research published in this series may include views on policy, but the institute itself takes no institutional policy positions. The IZA research network is committed to the IZA Guiding Principles of Research Integrity.

The Institute for the Study of Labor (IZA) in Bonn is a local and virtual international research center and a place of communication between science, politics and business. IZA is an independent nonprofit organization supported by Deutsche Post Foundation. The center is associated with the University of Bonn and offers a stimulating research environment through its international network, workshops and conferences, data service, project support, research visits and doctoral program. IZA engages in (i) original and internationally competitive research in all fields of labor economics, (ii) development of policy concepts, and (iii) dissemination of research results and concepts to the interested public.
\end{abstract}

IZA Discussion Papers often represent preliminary work and are circulated to encourage discussion. Citation of such a paper should account for its provisional character. A revised version may be available directly from the author. 


\section{ABSTRACT \\ Gender and Corruption: A Reassessment}

This paper analyzes the relationship between gender and corruption, controlling for countryspecific heterogeneity in a panel framework. Using annual observations in a pooled setting (no country-fixed effects) confirms the positive link between the involvement of women in society and the absence of corruption. However, once country-fixed effects are acknowledged, only the share of female employers remains a positive and statistically meaningful correlate. Nevertheless, the derived magnitude is negligible in a global sample. Analyzing potential nonlinearities reveals that this effect is driven by African nations, where a one standard deviation increase in the share of female employers is related to a substantial decrease of corruption by 2.5 index points (scale from zero to ten). Surprisingly, the link between the share of women in the labor force and the absence of corruption becomes negative once country unobservables are accounted for. Taken together, these findings cast doubt on a general, global relationship between gender and corruption.

\section{NON-TECHNICAL SUMMARY}

We analyze the relationship between gender roles and corruption. Contrary to previous findings, we find very little indication for the claim that a larger share of women in politics or business is associated with less corruption. Taking into account individual characteristics of each country, there appears to be no gender-corruption link. The only exception is provided by the link between the share of women as employers and the absence of corruption in Africa. These results show that the gender-corruption link can vary substantially by region.

JEL Classification: $\quad$ C23, D73, J16

Keywords: corruption, gender, panel data

Corresponding author:

Michael Jetter

Business School

University of Western Australia

8716 Hackett Drive

Crawley, WA 6009

Australia

E-mail:mjetter7@gmail.com 


\section{Introduction}

Over the past decades, governments and international organizations around the world have implemented policies aimed at increasing the share of women in politics and business. ${ }^{1}$ These policies are, at least partially, owed to a solid body of literature finding the average woman to be less corruptible than the average man. The corresponding studies usually rely on crosscountry evidence as data availability on both variables (participation of women in society and corruption) has been severely limited. This implies that the derived relationship between the role of women in society and corruption is based on cross-country variation, rather than withincountry variation.

However, unobservable heterogeneity across countries has been shown to matter in a number of related macroeconomic topics. For instance, determinants of growth (Islam, 1995), democracy (Acemoglu et al., 2008), and government size (Ram, 2009) can change fundamentally once country fixed effects are accounted for in a panel framework. As for the involvement of women in society, we now have substantial evidence of historical factors shaping gender roles around the world (Alesina et al., 2013). Similarly, cultural roots have been strongly associated with corruption levels (Fisman and Miguel, 2007; Barr and Serra, 2010). Thus, it is possible that the observed cross-country evidence on the link between gender and corruption can be traced to unobservable country-specific heterogeneity, at least in part.

The following pages study the link between gender and corruption using panel data for 117 countries over the years 1998 to 2011. Specifically, we distinguish between the role of women in politics and business, both as employers and employees. Taking advantage of better data availability than ever, we first replicate the benchmark result of larger female participation in parliament and the labor force being associated with less corruption. As a next step, we move to a pooled regression framework, analyzing annual values. The derived coefficients are consistent with the cross-sectional evidence, both in terms of statistical power and magnitude. Thus, the link between gender and corruption appears both in short-run and long-run cross-sectional analyses.

The main contribution of this paper then comes from the inclusion of country fixed effects

\footnotetext{
${ }^{1}$ For example, see the Millennium Development Goals, specifically Goal 3 (Promote Gender Equality and Empower Women), the OECD's Gender initiative, or Krook (2009).
} 
that are intended to control for any unobservable heterogeneity across countries. Notice that this does not only address historical differences, but also geographical, social, and any other countryspecific particularities one can imagine to affect gender roles or corruption. In econometric terms, the inclusion of country-fixed effects in a large panel data set can alleviate endogeneity concerns related to measurement error and omitted variable bias. ${ }^{2}$ Indeed, the derived results differ substantially from the previous estimates.

The share of women in parliament loses its power in explaining corruption levels, both in terms of statistical relevance and magnitude. In contrast, the share of female employers emerges as a positive and statistically powerful indicator. In turn, the female to male labor force ratio even produces a negative coefficient, indicating that an increased participation of women in the labor market is associated with increased corruption levels. However, magnitudes of all these effects remain negligible. For instance, a one standard deviation of the share of female employers (1.21 percentage points) would change the Corruptions Perceptions Index (CPI) by only 0.08 points. As the CPI ranges from zero to ten, this result is equivalent to approximately 3 percent of a standard deviation only. These results cast substantial doubt on the hypothesis linking gender to corruption in a general, global framework.

Finally, we analyze potential nonlinearities for the gender-corruption nexus, first along the lines of gender roles and income levels, and then across continents. In a related context, the determinants of economic growth (Masanjala and Papageorgiou, 2008) have been shown to vary by continent. Thus, it is possible that the gender-corruption link could also vary along these lines. Indeed, substantial differences emerge. The share of women in politics appears to contain corruption in Asia and Oceania. Moreover, female employers are strongly associated with lower corruption levels in Africa. This result is the only one that also carries meaningful implications in quantitative terms: raising the share of female employers by 10 percentage points would relate to a change in the CPI index by 2.5 points. For example, this implies the difference between the Central African Republic (CPI of 2.5) and Turkey (CPI of 5).

The paper is organized as follows. We begin with a short review of the available evidence related to the gender-corruption link. Section 3 describes our data and methodology. Section 4

\footnotetext{
${ }^{2}$ We acknowledge that our study cannot address potential issues stemming from reverse causality, as corruption may in itself affect gender quotas.
} 
discusses our findings and section 5 concludes.

\section{Background}

15 years ago, Dollar et al. (2001) and Swamy et al. (2001) produced the first quantitative evidence for a connection between gender and corruption. Their analyses are based on a substantial body of literature acknowledging women differences in behavioral characteristics across gender and suggesting that women might be less likely to sacrifice the common good for personal gain. Indeed, Dollar et al. (2001) find a a strong negative and statistically significant relationship between the level of female participation in politics and corruption. At the same time, Swamy et al. (2001) draw very similar conclusions, additionally examining the link between women in the labor force and corruption and using several independent data sets. Both studies conclude that encouraging more women to participate in politics might be beneficial for society. Potential explanations for such gender differences could come from the notion that women may be more relationship-orientated, have higher standards of ethical behavior and are more concerned with common good (Grove et al., 2011). Another explanation could be related to a difference in risk aversion of males and females (e.g., see Eckel and Füllbrunn, 2015, in a recent experimental study of financial decisions).

The two studies by Dollar et al. (2001) and Swamy et al. (2001) did not only contribute to the existing literature, but also initiated and supported distinct political implications. These and related findings have lead to governments bringing more women into political offices and bureaucratic positions, such as police forces or civil services. At least partly due to this reason, numerous countries have implemented quotas, specifically aiming at increasing the share of women in government. In fact, electoral gender quotas have been introduced in more than 100 countries across the world, including both developing and developed countries alike.

In Europe, eight countries have introduced legislated quotas that are compulsory for all political parties, most recently Greece and Ireland. It has been shown that the introduction of gender quotas has increased the average educational attainment of politicians (Baltrunaite et al., 2014) and education has been linked to the absence of corruption before (e.g., see Gatti, 2004, Arikan, 2004, or Glaeser and Saks, 2006). In Africa, gender quotas have been established 
in a growing number of countries. The legislated quota system has been established in eight countries, whereas informal political party quotas exist in twelve nations. Nevertheless, women represent only 19.8 percent of worldwide parliament members (Baltrunaite et al., 2014).

In addition, other unconventional measures have been taken even before the mentioned studies, referring to potential gender differences in corruptibility. For instance, in 1998, the Peruvian government decided to replace a part of the male traffic police of Lima by a new team consisting exclusively of female officers. More than a decade after this feminization initiative, follow-up research in Lima found a reduction in low-level corruption but persistent corruption among supervisors (Karim, 2011). Another women-only traffic force was established in 1999 by the chief police officer of Mexico City (Goetz, 2007, page 89). This traffic force was found to issue over three times as many tickets as the previous male police (Anozie et al., 2004, page 8). Similarly, but to a lesser extent, El Salvador, Panama, Ecuador, and Bolivia have incorporated women in their transit divisions (Karim, 2011). The idea of feminizing important decision-makers has also been put into practice in Uganda, where president Museveni assigned the majority of treasury positions in the new local government system to women (Goetz, 2007, page 89). In summary, quantitative studies about the existence or non-existence of a close link between gender and corruption could provide useful answers for policymakers.

However, most scientific studies share the shortcoming of comparing a cross-section of countries only at one point in time. In comparison, panel data could provide a better estimate of the female impact by observing sample countries over time. Thus, a panel data basis would allow us to exploit not only between-country variation, but also within countries. This would reduce the risk that women's presence in politics and its link to corruption could be driven by country-specific characteristics that are associated with both a higher participation of women and corruption (i.e., omitted variables). For example, low levels of corruption and high female political participation could be the result of both a liberal democracy that simultaneously encourages gender equality and good governance (Rivas, 2013, p.10f.). Further, relying on within-country variation is likely to alleviate concerns about measurement error in comparing corruption perceptions across countries and cultures. 


\section{Data and Methodology}

\subsection{Data}

All information used in this analysis comes from standard sources for macroeconomic data, displayed in Table 1. First, we access the CPI, the benchmark source for cross-country information on corruption provided by Transparency International, for our measure of corruption levels. The CPI provides annual values for a large number of countries from 1998 to 2011, ranging from zero to ten, where higher values indicate less corruption. ${ }^{3}$ Thus, the index measures the absence of corruption.

Table 1: Summary statistics for annual values from 1998 to 2011 for 951 observations in 117 countries.

\begin{tabular}{|c|c|c|c|c|}
\hline Variable & $\begin{array}{c}\text { Mean } \\
\text { (Std. Dev.) }\end{array}$ & $\begin{array}{l}\text { Min. } \\
\text { Max. }\end{array}$ & Source $^{a}$ & Explanation \\
\hline CPI & $\begin{array}{l}4.98 \\
(2.31)\end{array}$ & $\begin{array}{l}1.3 \\
10\end{array}$ & $\mathrm{TI}$ & $\begin{array}{l}\text { Ranging from } 0 \text { to } 10 \text { with higher } \\
\text { values indicating less corruption }\end{array}$ \\
\hline$\%$ women in parliament & $\begin{array}{c}17.93 \\
(10.23)\end{array}$ & $\begin{array}{c}0 \\
47.30\end{array}$ & WB & $\begin{array}{l}\text { Share of women in } \\
\text { parliament }\end{array}$ \\
\hline$\%$ employers female & $\begin{array}{c}2.12 \\
(1.22)\end{array}$ & $\begin{array}{c}0 \\
8.40\end{array}$ & ILO & $\begin{array}{l}\text { Share of women in } \\
\text { total employers }\end{array}$ \\
\hline $\begin{array}{l}\text { Female to male } \\
\text { ratio labor force }\end{array}$ & $\begin{array}{c}68.53 \\
(16.03)\end{array}$ & $\begin{array}{c}16.27 \\
105.40\end{array}$ & ILO & $\begin{array}{l}\text { Share of women in } \\
\text { total labor force }\end{array}$ \\
\hline GDP per capita & $\begin{array}{c}15,534.28 \\
(17,644.58)\end{array}$ & $\begin{array}{c}162.81 \\
86,127.24\end{array}$ & WB & Ln(GDP per capita) \\
\hline Population / 100,000 & $\begin{array}{c}311.72 \\
(736.48)\end{array}$ & $\begin{array}{c}4.25 \\
12,056.25\end{array}$ & WB & $\operatorname{Ln}($ population $/ 100,000$ ) \\
\hline $\begin{array}{l}\text { Primary education, } \\
\text { duration (years) }\end{array}$ & $\begin{array}{c}5.53 \\
(0.95)\end{array}$ & $\begin{array}{l}3 \\
8\end{array}$ & WB & $\begin{array}{l}\text { Duration of primary } \\
\text { education in years }\end{array}$ \\
\hline
\end{tabular}

Notes: ${ }^{a} \mathrm{TI}=$ Transparency International; WB $=$ World Bank; ILO = International Labour Organization.

Although no indicator of corruption levels is free from measurement error, the CPI has emerged as the benchmark index in cross-country corruption studies. This is mostly based on the fact that the CPI includes people's perceptions and expert analyses, conducted to assess the risk level of doing business in a country. As these two viewpoints can differ, but both provide meaningful information on existing corruption levels, mixed indices are usually preferred. For a more detailed discussion of choosing the CPI, we refer to Knack and Azfar (2000), Serra

\footnotetext{
${ }^{3}$ Measurement of the CPI changes after 2011, making values incomparable to previous observations.
} 
(2006, page 5), and Urra (2007). Nevertheless, all results are robust when using the Control of Corruption indicator provided from the Worldwide Governance Indicators (Kaufmann et al., 2011).

Our indicators for the role of gender in society come from two main sources. First, the World Bank provides information on the share of women in parliament. We use this information as an indicator for the involvement of women in politics, as the majority of the related literature focuses on politics (Dollar et al., 2001; Swamy et al., 2001)). Second, we access the International Labour Organization's database to gather information on the percentage of employers and employees that are female. Several studies have considered the share of women in parliament and the labor force before (Dollar et al., 2001; Swamy et al., 2001), but fewer researchers have considered the share of female employers. Note that corruption, defined as the "misuse of public power for private gain" (Treisman, 2000), involves a public official and a private citizen or a business. Thus, it is equally relevant to analyze the role of gender on both sides of the table, both for the bribee (the public official) and the briber (private citizens and businesses).

To get an idea of the general correlation between gender roles in society and corruption levels across countries, Table 2 presents basic correlation values between the CPI and the three measures for the role of women in society. Note that the share of women in parliament and in the labor force both correlate strongly with corruption values (0.52 and 0.31$)$, more so than the share of female employers (0.18). It is somewhat surprising to see the relatively low correlation between the share of women as business leaders and the other two gender indices. Thus, it may well matter where women are involved in society with respect to corruption, warranting a detailed analysis.

Table 2: Cross-correlation table for annual values from 1998 to 2013 for 1,047 observations.

\begin{tabular}{lcccc}
\hline \hline \multicolumn{1}{c}{ Variables } & CPI & $\begin{array}{c}\text { \% women in } \\
\text { parliament }\end{array}$ & $\begin{array}{c}\% \text { employers } \\
\text { female }\end{array}$ & $\begin{array}{c}\text { Female to male ratio } \\
\text { labor force }\end{array}$ \\
\hline CPI & 1 & & & \\
$\begin{array}{l}\% \text { women in parliament } \\
\% \text { employers female }\end{array}$ & 0.52 & 1 & & \\
Female to male ratio labor force & 0.18 & 0.14 & 1 & 1 \\
\hline \hline
\end{tabular}

Further, Figure 1 displays basic descriptive graphs, displaying how the three gender indices 
relate to corruption in a pure cross-sectional setting. In this case, we take all available yearly observations and average them for every sample country. We also display the LOWESS curve between both variables (locally weighted regression), allowing us to assess the basic descriptive relationship without requiring any advanced specification of the functional form (Cleveland, 1979; Jacoby, 2000). As a reference point, the bottom right graph of Figure 1 displays the relationship between the CPI and income levels, the most persistent corruption determinant in the corresponding literature (Treisman, 2000; Serra, 2006; Gundlach and Paldam, 2009). Notice that the gender indices show a relatively scattered picture when plotted against the CPI, especially when compared to the GDP per capita graph. Thus, at first glance we may not expect a meaningful relationship between gender roles and corruption in a cross-country analysis.

Women in parliament

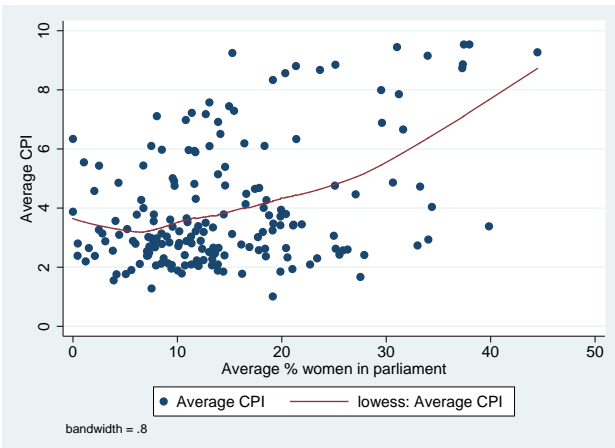

Ratio of female to male labor force

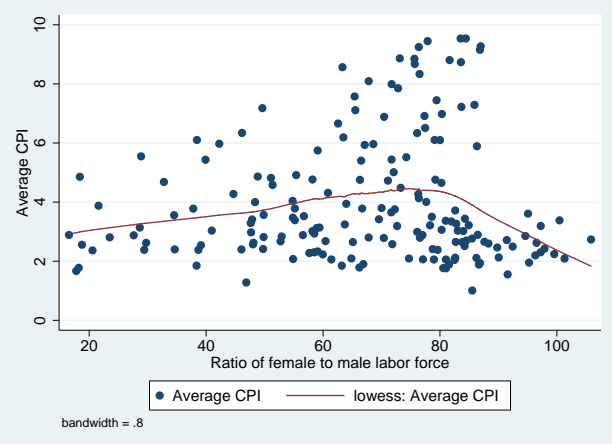

Female employers $(\%)$

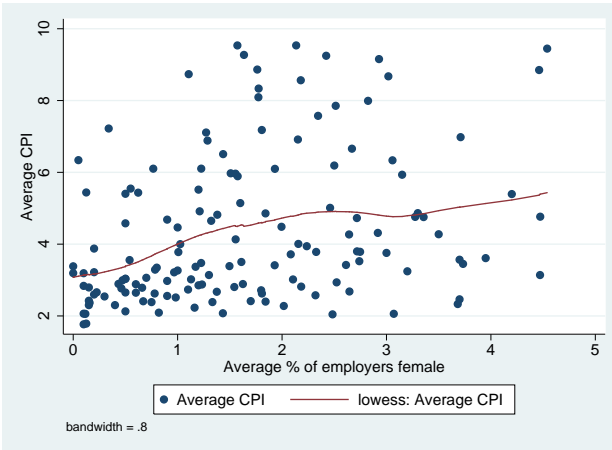

Ln(GDP per capita)

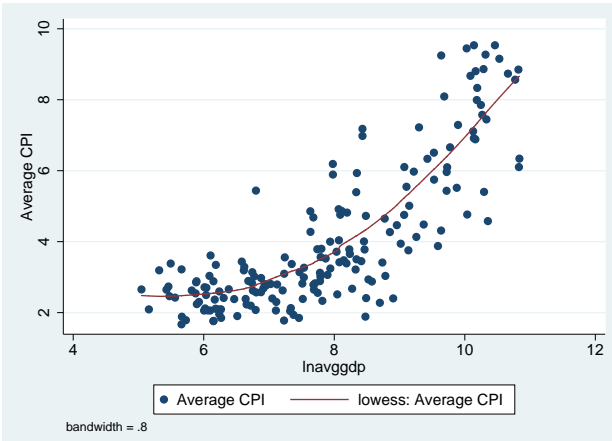

Figure 1: Relationship between corruption and potential determinants. Using averages for all variables from 1998 to 2011 (117 countries).

Beyond the role of gender in explaining corruption, several other factors have been proposed in the associated literature. To better isolate the link between gender and corruption, we there- 
fore incorporate these variables as controls in the regression analysis. Specifically, we include GDP per capita and population size, in addition to proxies for education and institutions. ${ }^{4}$ Note that even though the associated literature has produced (weaker) evidence for other variables to be associated with corruption levels, these variables usually only change slowly over time, if at all. For example, colonial origin, a common law system, a federal structure, ethnic and religious compositions, or geographical components of a country are either fixed over time or are unlikely to change within a few years. In addition, variables such as ethnic or religious population shares are usually not available on a yearly basis for a large number of countries. Thus, we do not include these variables in our analysis.

Finally, Table 3 presents a list of sample countries, where information on all respective variables is available. For consistency across estimations, we only include a country-year observation if information for all variables is available. Nevertheless, all results are robust to using additional information when possible. ${ }^{5}$

\subsection{Methodology}

Our empirical strategy begins with a conventional cross-sectional analysis by taking averages over all available information for each country. Specifically, for country $i$ we estimate

$$
C P I_{i}=\alpha_{0}+\alpha_{1} \text { Female }_{i}+\alpha_{2} \boldsymbol{X}_{i}+\delta_{i}
$$

where Female $_{i}$ constitutes the respective measure for women's involvement in business and politics and $\boldsymbol{X}_{\boldsymbol{i}}$ incorporates the control variables introduced above. Everything else equal, the majority of the related literature has found a positive, statistically powerful, and quantitatively meaningful coefficient for $\alpha_{1}$, predicting a larger CPI (more absence of corruption) with higher shares of women.

\footnotetext{
${ }^{4}$ For the link between income levels and corruption, we refer to Treisman (2000), Serra (2006), or Gundlach and Paldam (2009). For the link between population size and corruption, see Fisman and Gatti (2002), Knack and Azfar (2003), or Mocan (2008). For the role of education, one may consult Svensson (2005), Glaeser and Saks (2006), or Dincer (2008). Swamy et al. (2001), Gatti (2004), and Jetter et al. (2015) highlight the importance of democracy.

${ }^{5}$ In addition, we exclude two observations that show a large and unusual jump in the share of female employers: Bhutan in 2012 and Indonesia in 2013. Both observations display shares of female employers way above ten percent and both countries have shown relatively minor shares in prior observations ( 0.2 for Bhutan and 1.3 for Indonesia). Nevertheless, all results are robust to including these two outliers.
} 


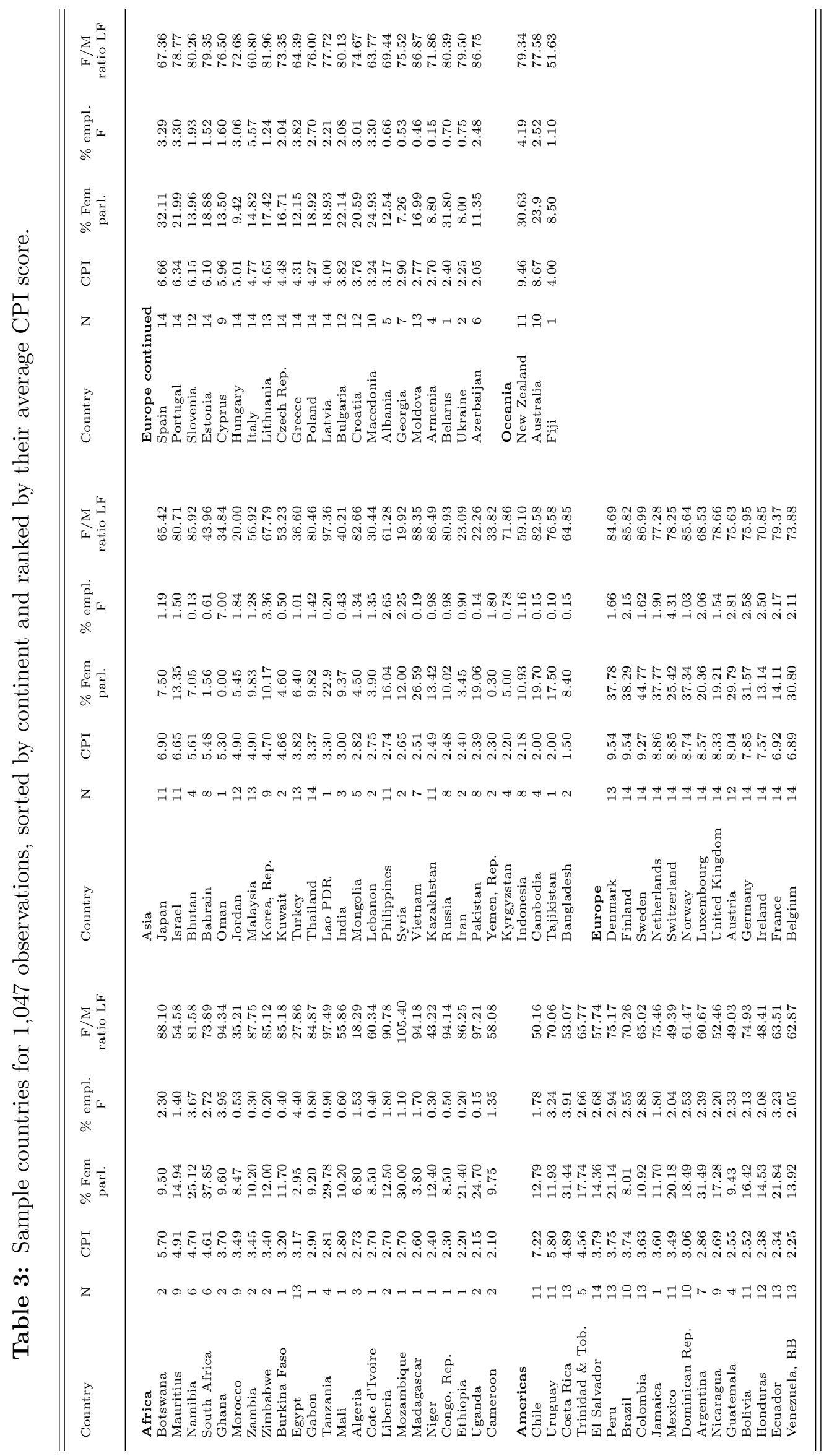


We then move to analyzing the relationship between gender compositions and corruption in a pooled panel data set, using annual observations. Specifically, for year $t$ (with $1998 \leq t \leq 2011$ ) we estimate

$$
C P I_{i t}=\beta_{0}+\beta_{1} \text { Female }_{i t}+\beta_{2} \boldsymbol{X}_{i t}+\epsilon_{i t}
$$

If the relationship between gender and corruption holds in the short- as well as in the longrun, then $\beta_{1}$ should not differ fundamentally from $\alpha_{1}$, derived in equation 1 . To exploit the panel structure of repeated annual observations, we then turn toward a fixed effect estimation, extending equation 2 to

$$
C P I_{i t}=\gamma_{0}+\gamma_{1} \text { Female }_{i t}+\gamma_{2} \boldsymbol{X}_{i t}+\gamma_{3} \boldsymbol{\lambda}_{\boldsymbol{i}}+\omega_{i t}
$$

where $\boldsymbol{\lambda}_{\boldsymbol{i}}$ introduces binary indicators for each sample country. Thus, equation 3 only takes advantage of within-country variation in gender indices (and all other control variables) and eliminates between-country differences that may stem from deep underlying country-specific particularities, such as culture, history, or geography.

In summary, if the link between gender and corruption was indeed present, then we would expect $\gamma_{1}$ to produce a statistically meaningful coefficient. Finally, we note that throughout all estimations standard errors $\left(\delta_{i}, \epsilon_{i t}\right.$, and $\left.\omega_{i t}\right)$ are clustered on the country level.

\section{Empirical Findings}

This section describes the empirical findings for the analysis of all three gender variables in their relationship to the CPI. Each subsection begins by analyzing the data as a pure cross section and then moves to analyzing pooled panel data, before introducing country fixed effects. Finally, potential nonlinearities are considered.

\subsection{Women in Politics and Corruption}

Table 4 begins by analyzing the potential link between the share of women in parliament and corruption. Columns (1) and (2) consider a pure cross-sectional relationship, where variables are averaged for each country. Columns (3) and (4) analyze the data as a pooled sample of annual 
observations and the final columns focus on a panel analysis including country-fixed effects.

Table 4: Baseline regression results, estimating the relationship between \% women in parliament and the absence of corruption (CPI index).

\begin{tabular}{|c|c|c|c|c|c|c|}
\hline & & $(2)$ & $(3)$ & $(4)$ & $(5)$ & $(6)$ \\
\hline & \multicolumn{2}{|c|}{ Cross-Section } & \multicolumn{2}{|c|}{ Pooled } & \multicolumn{2}{|c|}{ Fixed Effects } \\
\hline$\%$ women in parliament & $\begin{array}{c}0.109^{* * *} \\
(0.022)\end{array}$ & $\begin{array}{l}0.043^{*} \\
(0.013)\end{array}$ & $\begin{array}{c}0.113^{* * *} \\
(0.019)\end{array}$ & $\begin{array}{c}0.038^{* * *} \\
(0.012)\end{array}$ & $\begin{array}{c}0.007 \\
(0.007)\end{array}$ & $\begin{array}{c}0.003 \\
(0.009)\end{array}$ \\
\hline GDP per capita & & $\begin{array}{c}0.994^{* * *} \\
(0.077)\end{array}$ & & $\begin{array}{c}1.277^{* * *} \\
(0.088)\end{array}$ & & $\begin{array}{c}0.851^{* * *} \\
(0.221)\end{array}$ \\
\hline Population size & & $\begin{array}{l}-0.049 \\
(0.073)\end{array}$ & & $\begin{array}{c}-0.130^{*} \\
(0.071)\end{array}$ & & $\begin{array}{c}-1.652^{* * *} \\
(0.500)\end{array}$ \\
\hline Education & & $\begin{array}{c}0.368^{* * *} \\
(0.093)\end{array}$ & & $\begin{array}{c}0.333^{* * *} \\
(0.099)\end{array}$ & & $\begin{array}{c}0.111 \\
(0.084)\end{array}$ \\
\hline Polity IV & & $\begin{array}{c}0.031 \\
(0.021)\end{array}$ & & $\begin{array}{l}-0.026 \\
(0.025)\end{array}$ & & $\begin{array}{l}-0.006 \\
(0.018)\end{array}$ \\
\hline$N$ & 117 & 117 & 951 & 951 & 951 & 951 \\
\hline \# of countries & 117 & 117 & 117 & 117 & 117 & 117 \\
\hline$R^{2}$ & 0.221 & 0.735 & 0.256 & 0.762 & 0.975 & 0.977 \\
\hline
\end{tabular}

Notes: Standard errors clustered on the country level in parentheses. ${ }^{*} p<0.10,{ }^{* *} p<0.05,{ }^{* * *} p<0.01$.

Beginning with a cross-sectional analysis, the univariate estimation reveals a firmly positive relationship between the share of women in parliament and the absence of corruption. A quantitative interpretation of the derived coefficient would suggest that an increase of the share of women in parliament by one standard deviation (10.35 percentage points) would be associated with an increase in the CPI by about one index point. As the CPI runs from zero to ten, this magnitude would be relatively sizeable, corresponding to approximately 43 percent of one standard deviation.

Nevertheless, the estimation displayed in column (1) is likely to suffer from an omitted variable bias, as several other covariates have been proposed by the associated literature. Thus, column (2) includes the most commonly found corruption determinants in the regression framework. The coefficient of interest decreases to approximately 40 percent of its initial magnitude, but statistical power remains high. In addition, note that the associated standard error de- 
creases, indicating a better fit of this more complete regression.

Further, the derived coefficients of the respective control variables confirm findings in the previous literature. Richer and more educated countries are strongly linked to lower corruption levels, whereas population size and democracy barely matter. Throughout our estimations, the respective coefficients associated with these control variables generally remain consistent with the literature, so we will not focus on discussing them.

Moving to analyzing annual observations in a pooled setting, columns (3) and (4) produce coefficients that are remarkably similar to the first estimates, both in the univariate framework and when adding further covariates. Thus, the relationship between women in parliament and corruption emerges for either a long-run perspective when averaging variables over 14 years (1998 to 2011), but also when evaluating annual observations, as in Dollar et al. (2001). This further merits a more detailed analysis of yearly data.

Finally, columns (5) and (6) incorporate country-fixed effects. Now we find substantial differences for the explanatory power of the share of women in parliament. The respective coefficient decreases markedly to 0.007 without further regressors (compared to 0.109 and 0.113 before) and to 0.003 when adding further control variables (compared to 0.043 and 0.038 before). In the final and most complete estimation, the coefficient associated with women in parliament remains far from conventional levels of statistical significance. In addition, the quantitative interpretation of the derived coefficient would suggest a negligible magnitude: one standard deviation of the share of women in parliament (10.35) would be associated with an increase in the CPI by 0.03 index points or only 1.4 percent of a standard deviation.

However, this baseline estimation considers the relationship between women in parliament and corruption in a linear fashion. Table 5 displays results from extending the most complete estimation in column (6) of Table 4 toward including nonlinearities. A priori, it is possible that the effect is quadratic or varies along the lines of development levels, the most persistent predictor of corruption. ${ }^{6}$

Column (1) adds a quadratic term of the share of women in parliament, whereas column (2) introduces an interaction term with income levels. However, none of the two estimations produce

\footnotetext{
${ }^{6}$ In a related context, Jetter et al. (2015) have found a nonlinear effect of democracy on corruption along the lines of income levels.
} 
Table 5: Checking for nonlinearities, estimating the relationship between $\%$ women in parliament and the absence of corruption (CPI index).

\begin{tabular}{|c|c|c|c|c|c|c|}
\hline & (1) & $(2)$ & $\begin{array}{c}(3) \\
\text { Africa }\end{array}$ & $\begin{array}{c}(4) \\
\text { Asia \& } \\
\text { Oceania }\end{array}$ & $\begin{array}{c}(5) \\
\text { Europe }\end{array}$ & $\begin{array}{c}(6) \\
\text { Americas }\end{array}$ \\
\hline$\%$ women in parliament & $\begin{array}{c}0.002 \\
(0.016)\end{array}$ & $\begin{array}{l}-0.025 \\
(0.043)\end{array}$ & $\begin{array}{c}0.008 \\
(0.025)\end{array}$ & $\begin{array}{c}0.035^{* * *} \\
(0.012)\end{array}$ & $\begin{array}{c}0.002 \\
(0.017)\end{array}$ & $\begin{array}{c}-0.014^{*} \\
(0.008)\end{array}$ \\
\hline$(\% \text { women in parliament })^{2}$ & $\begin{array}{c}0.000 \\
(0.000)\end{array}$ & & & & & \\
\hline $\begin{array}{l}\% \text { women in parliament } \times \\
\text { GDP per capita }\end{array}$ & & $\begin{array}{c}0.003 \\
(0.005)\end{array}$ & & & & \\
\hline $\begin{array}{l}\text { Control variables }{ }^{a} \& \\
\text { country FE }\end{array}$ & yes & yes & yes & yes & yes & yes \\
\hline$N$ & 951 & 951 & 73 & 227 & 443 & 208 \\
\hline \# of countries & 117 & 117 & 23 & 35 & 38 & 20 \\
\hline
\end{tabular}

Notes: Standard errors clustered on the country level in parentheses.

${ }^{*} p<0.10,{ }^{* *} p<0.05,{ }^{* * *} p<0.01$.

${ }^{a}$ Includes GDP per capita, population size, education, and the polity IV index. 
relevant findings. Thus, in a global sample, the relationship between women in parliament and corruption levels disappears once country-specific heterogeneity is taken into account.

Further, columns (3) to (6) re-estimate the main regression for continent-specific subsamples. The relationship only produces a positive and statistically powerful coefficient in Asian and Oceanian countries. With a magnitude of 0.035 , a one standard deviation of the share of women in parliament in these nations would be related to an increase in the CPI by 0.36 index points. Although this result is not nearly as quantitatively powerful as the link between income levels and corruption, it does produce some insight.

The only other statistically meaningful result is produced by the American subsample and, surprisingly, the respective coefficient turns negative. This suggests that more women in politics could even relate to more corruption. Nevertheless, the respective result is only statistically significant on the margin and the related magnitude appears minimal. In the rest of the world, we observe no discernable link between women in parliament and corruption.

\subsection{Women as Employers and Corruption}

From measuring the role of women in politics, we now move to business-related variables. First, we focus on the role of women as employers and the potential relationship with corruption levels. Following the same structure as before, Table 6 begins by moving from a pure cross-sectional estimation over a pooled analysis of annual data to panel regressions with country-fixed effects.

Column (1) reveals a basic positive correlation between the share of female employers and the absence of corruption. In terms of magnitude, one standard deviation increase in the share of female employers (1.21 percentage points) would be associated with a 0.84 point increase in the CPI index - a result that would be relatively meaningful. However, once our set of control variables is included, the coefficient turns firmly insignificant, even negative, but indistinguishable from zero. Thus, once the conventional control variables are taken into account, the cross-country evidence for a potential link between women as employers and corruption vanishes.

Moving to the respective results from analyzing annual values in a pooled setting, columns (3) and (4) then provide similar results. We first encounter a positive link, but the inclusion of further regressors renders the coefficient on the female share of employers firmly insignificant on 
Table 6: Baseline regression results, estimating the relationship between $\%$ employers female and the absence of corruption (CPI index).

\begin{tabular}{|c|c|c|c|c|c|c|}
\hline & $(1)$ & $(2)$ & $(3)$ & $(4)$ & $(5)$ & $(6)$ \\
\hline & \multicolumn{2}{|c|}{ Cross-Section } & \multicolumn{2}{|c|}{ Pooled } & \multicolumn{2}{|c|}{ Fixed Effects } \\
\hline$\%$ employers female & $\begin{array}{c}0.696^{* * *} \\
(0.168)\end{array}$ & $\begin{array}{c}-0.095 \\
(0.119)\end{array}$ & $\begin{array}{c}0.330^{* *} \\
(0.161)\end{array}$ & $\begin{array}{c}-0.110 \\
(0.100)\end{array}$ & $\begin{array}{c}0.066^{*} \\
(0.037)\end{array}$ & $\begin{array}{c}0.066^{*} \\
(0.036)\end{array}$ \\
\hline Control variables ${ }^{a}$ & & yes & & yes & & yes \\
\hline$N$ & 117 & 117 & 951 & 951 & 951 & 951 \\
\hline \# of countries & 117 & 117 & 117 & 117 & 117 & 117 \\
\hline$R^{2}$ & 0.128 & 0.712 & 0.030 & 0.743 & 0.975 & 0.977 \\
\hline
\end{tabular}

Notes: Standard errors clustered on the country level in parentheses.

${ }^{*} p<0.10,{ }^{* *} p<0.05,{ }^{* * *} p<0.01$.

${ }^{a}$ Includes GDP per capita, population size, education, and the polity IV index.

conventional levels of statistical relevance. From these estimates we would not expect the final estimation including country-fixed effects to produce a relevant result for the share of female employers.

However, incorporating country-fixed effects in columns (5) and (6) produces a surprising finding: having more female employers does indeed seem to be associated with decreased corruption levels and the result is statistically meaningful on the ten percent level. Once countryspecific unobservables are acknowledged, even the inclusion of the usual set of covariates leaves the coefficient of interest powerful. Nevertheless, a one standard deviation of the share of female employers would relate to a change in the CPI by 0.08 index points - a result that is virtually zero.

To gain a better understanding of the importance of female employers in explaining corruption, Table 7 displays results from analyzing potential nonlinearities. Once again, we do not find evidence for a quadratic relationship or a meaningful interaction with income levels. Thus, the relationship between female employers and corruption does not seem to vary for poorer or richer countries.

However, the distinction by continents provides telling results. The strong positive associa- 
Table 7: Checking for nonlinearities, estimating the relationship between the $\%$ employers female and the absence of corruption (CPI index).

\begin{tabular}{|c|c|c|c|c|c|c|}
\hline & (1) & $(2)$ & $\begin{array}{c}(3) \\
\text { Africa }\end{array}$ & $\begin{array}{c}(4) \\
\text { Asia \& } \\
\text { Oceania }\end{array}$ & $\begin{array}{c}(5) \\
\text { Europe }\end{array}$ & $\begin{array}{c}(6) \\
\text { Americas }\end{array}$ \\
\hline$\%$ employers female & $\begin{array}{c}0.089 \\
(0.075)\end{array}$ & $\begin{array}{c}0.232 \\
(0.166)\end{array}$ & $\begin{array}{c}0.203^{* * *} \\
(0.065)\end{array}$ & $\begin{array}{c}0.079 \\
(0.080)\end{array}$ & $\begin{array}{c}0.035 \\
(0.042)\end{array}$ & $\begin{array}{c}0.104 \\
(0.110)\end{array}$ \\
\hline$(\% \text { employers female })^{2}$ & $\begin{array}{l}-0.003 \\
(0.008)\end{array}$ & & & & & \\
\hline $\begin{array}{l}\% \text { employers female } \times \\
\text { GDP per capita }\end{array}$ & & $\begin{array}{l}-0.018 \\
(0.017)\end{array}$ & & & & \\
\hline $\begin{array}{l}\text { Control variables }{ }^{a} \& \\
\text { country FE }\end{array}$ & yes & yes & yes & yes & yes & yes \\
\hline$N$ & 951 & 951 & 73 & 227 & 443 & 208 \\
\hline \# of countries & 117 & 117 & 23 & 35 & 38 & 20 \\
\hline
\end{tabular}

Notes: Standard errors clustered on the country level in parentheses.

${ }^{*} p<0.10,{ }^{* *} p<0.05,{ }^{* * *} p<0.01$.

${ }^{a}$ Includes GDP per capita, population size, education, and the polity IV index. 
tion of female employers and corruption in the global sample is mostly driven by variation within African nations. Here, the derived coefficient implies that a one standard deviation of the share of women as employers would relate to a 0.25 point change in the CPI. In other words, raising the share of female employers by four percentage points could be associated with a full point increase in the CPI scale. This result is much more powerful in magnitude than the corresponding finding for the share of women in politics.

\subsection{Women in the Labor Force and Corruption}

The third and final variable of women's involvement in their country's society measures the ratio of female to male labor force participation. Table 8 replicates the familiar sequence of regressions, whereas Table 9 focuses on potential nonlinearities.

Table 8: Baseline regression results, estimating the relationship between the female to male ratio labor force and the absence of corruption (CPI index).

\begin{tabular}{|c|c|c|c|c|c|c|}
\hline & & $(2)$ & (3) & $(4)$ & $(5)$ & $(6)$ \\
\hline & \multicolumn{2}{|c|}{ Cross-Section } & \multicolumn{2}{|c|}{ Pooled } & \multicolumn{2}{|c|}{ Fixed Effects } \\
\hline $\begin{array}{l}\text { Female to male ratio } \\
\text { labor force }\end{array}$ & $\begin{array}{l}0.014^{*} \\
(0.009)\end{array}$ & $\begin{array}{c}0.017^{* * *} \\
(0.005)\end{array}$ & $\begin{array}{c}0.045^{* * *} \\
(0.012)\end{array}$ & $\begin{array}{l}0.016^{* *} \\
(0.008)\end{array}$ & $\begin{array}{l}-0.013 \\
(0.009)\end{array}$ & $\begin{array}{r}-0.019^{*} \\
(0.010)\end{array}$ \\
\hline Control variables ${ }^{a}$ & & yes & & yes & & yes \\
\hline$N$ & 117 & 117 & 951 & 951 & 951 & 951 \\
\hline \# of countries & 117 & 117 & 117 & 117 & 117 & 117 \\
\hline$R^{2}$ & 0.017 & 0.731 & 0.099 & 0.750 & 0.975 & 0.977 \\
\hline
\end{tabular}

Notes: Standard errors clustered on the country level in parentheses.

${ }^{*} p<0.10,{ }^{* *} p<0.05,{ }^{* * *} p<0.01$.

${ }^{a}$ Includes GDP per capita, population size, education, and the polity IV index.

Beginning with pure cross-sectional evidence, we observe a similar pattern as with the share of women in parliament. The relationship is positive and statistically powerful in a univariate regression framework. Including the usual set of control variables then further stabilizes the coefficient, as standard errors are almost cut in half and the coefficient remains at 0.017. A quantitative interpretation would suggest a one standard deviation of the share of women in the labor force (15.93) to change the CPI by 0.27 index points. 
Moving to a pooled analysis of yearly data produces a very comparable estimate in the complete regression with a coefficient of 0.16 . Thus, if there was any relationship between the gender composition of the labor market and corruption levels, then this link appears to emerge once again both in long- and short-run analyses of yearly observations.

However, as with the other gender variables, incorporating country-fixed effects changes the derived conclusion substantially. In fact, the coefficient of interest turns negative and once the usual control variables are accounted for this finding is statistically powerful on the ten percent level. This result is surprising and stands in contrast to virtually all related studies in this literature. Taken literally, a one standard deviation increase of the share of women in the labor force is suggested to decrease the CPI by 0.30 index points.

With this surprising result, considering potential nonlinearities and heterogeneities across continents could potentially produce telling results. Table 9 displays the respective results and we once again notice that the relationship does not seem to be quadratic and neither does it seem to vary along the lines of income levels, the baseline determinant of corruption.

Table 9: Checking for nonlinearities, estimating the relationship between the female to male ratio labor force and the absence of corruption (CPI index).

\begin{tabular}{|c|c|c|c|c|c|c|}
\hline & $(1)$ & $(2)$ & $\begin{array}{c}(3) \\
\text { Africa }\end{array}$ & $\begin{array}{c}(4) \\
\text { Asia \& } \\
\text { Oceania }\end{array}$ & $\begin{array}{l}(5) \\
\text { Europe }\end{array}$ & $\begin{array}{c}(6) \\
\text { Americas }\end{array}$ \\
\hline Female to male ratio labor force & $\begin{array}{l}-0.022 \\
(0.034)\end{array}$ & $\begin{array}{l}-0.069^{*} \\
(0.037)\end{array}$ & $\begin{array}{l}-0.045 \\
(0.058)\end{array}$ & $\begin{array}{l}-0.008 \\
(0.017)\end{array}$ & $\begin{array}{c}-0.031^{* *} \\
(0.015)\end{array}$ & $\begin{array}{l}-0.015 \\
(0.025)\end{array}$ \\
\hline$(\text { Female to male ratio labor force })^{2}$ & $\begin{array}{c}0.000 \\
(0.000)\end{array}$ & & & & & \\
\hline $\begin{array}{l}\text { Female to male ratio labor force } \times \\
\text { GDP per capita }\end{array}$ & & $\begin{array}{c}0.005 \\
(0.004)\end{array}$ & & & & \\
\hline $\begin{array}{l}\text { Control variables }{ }^{a} \& \\
\text { country FE }\end{array}$ & yes & yes & yes & yes & yes & yes \\
\hline$N$ & 951 & 951 & 73 & 227 & 443 & 208 \\
\hline \# of countries & 117 & 117 & 23 & 35 & 38 & 20 \\
\hline
\end{tabular}

Notes: Standard errors clustered on the country level in parentheses. ${ }^{*} p<0.10,{ }^{* *} p<0.05,{ }^{* * *} p<0.01$.

${ }^{a}$ Includes GDP per capita, population size, education, and the polity IV index. 
However, separating the data by continent provides a clue as to where the derived link seems to matter. Especially in European countries do we observe a negative link between the share of women in the labor force and the CPI. The coefficient here is stronger than in the global sample (-0.031 versus -0.019), suggesting a one standard deviation increase of the female share in the workforce to lower the CPI index by almost 0.5 basis points. Further, although not statistically significant on conventional levels, this negative link also emerges for African countries. This is particularly surprising as the share of female employers seems to improve corruption standards in Africa - the share of women in the labor force appears to be related to the opposite. Note that the coefficient in the African sample produces a powerful link in terms if magnitude (-0.045), but the lack of statistical power could be related to the much smaller sample size (73, as opposed to 443 in Europe) and the resulting elevated standard errors.

Overall, the introduction of country-fixed effects, acknowledging unobservable differences across countries, produces estimates that differ substantially from the corresponding results from analyzing a pure cross-sectional or pooled sample.

\section{Conclusion}

This paper analyzes whether corruption levels are related to the involvement of women in politics or business. Our main extension stems from the inclusion of country-fixed effects, thereby acknowledging deeply rooted differences between countries in terms of culture, history, and geography. With 14 years of annual observations between 1998 and 2011, we derive an unbalanced panel data set of 951 observations in 117 countries.

Our results from analyzing pure country averages confirm the conventional results in the associated literature: more women in politics and business are associated with less corruption. Analyzing a pooled sample underscores this finding, both in terms of statistical power and magnitude. Thus, analyzing the gender-corruption link using annual data is likely to reveal underlying relationships, if any. However, once we incorporate country-fixed effects, only the share of female employers remains a positive predictor of the CPI, indicating less corruption. In quantitative terms, the relationship is particularly strong in African nations. Thus, differences across continents in the gender-corruption nexus appear likely, a result that resembles the literature 
surrounding heterogeneity in growth determinants (Masanjala and Papageorgiou, 2008).

Finally, a surprising result appears when analyzing the link between the share of women in the labor force and corruption in a fixed effects framework. Our findings point toward a negative relationship between this fraction and the CPI, indicating that more women in the workforce are related to more corruption.

Overall, this paper demonstrates that unobservable differences across countries should not be neglected when analyzing the link between gender and corruption. As forcefully demonstrated by Alesina et al. (2013), gender roles in every particular society have been shaped differently. Understanding the link between gender and corruption should not ignore such heterogeneity.

\section{References}

Acemoglu, D., Johnson, S., Robinson, J. A., and Yared, P. (2008). Income and democracy. American Economic Review, 98(3):808-842.

Alesina, A., Giuliano, P., and Nunn, N. (2013). On the origins of gender roles: Women and the plough. The Quarterly Journal of Economics, 128(2):469-530.

Anozie, V., Shinn, J., Skarlatos, K., and Urzua, J. (2004). Reducing incentives for corruption in the Mexico City police force. International Workshop, Public Affairs, 869:2003-2004.

Arikan, G. G. (2004). Fiscal decentralization: A remedy for corruption? International Tax and Public Finance, 11(2):175-195.

Baltrunaite, A., Bello, P., Casarico, A., and Profeta, P. (2014). Gender quotas and the quality of politicians. Journal of Public Economics, 118:62-74.

Barr, A. and Serra, D. (2010). Corruption and culture: An experimental analysis. Journal of Public Economics, 94(11):862-869.

Cleveland, W. S. (1979). Robust locally weighted regression and smoothing scatterplots. Journal of the American Statistical Association, 74(368):829-836.

Dincer, O. C. (2008). Ethnic and religious diversity and corruption. Economics Letters, 99(1):98102. 
Dollar, D., Fisman, R., and Gatti, R. (2001). Are women really the "fairer" sex? Corruption and women in government. Journal of Economic Behavior $\&$ Organization, 46(4):423-429.

Eckel, C. C. and Füllbrunn, S. (2015). Thar SHE blows? Gender, competition, and bubbles in experimental asset markets. American Economic Review, 105(2):906-20.

Fisman, R. and Gatti, R. (2002). Decentralization and corruption: Evidence across countries. Journal of Public Economics, 83(3):325-345.

Fisman, R. and Miguel, E. (2007). Corruption, norms, and legal enforcement: Evidence from diplomatic parking tickets. Journal of Political Economy, 115(6):1020-1048.

Gatti, R. (2004). Explaining corruption: Are open countries less corrupt? Journal of International Development, 16(6):851-861.

Glaeser, E. L. and Saks, R. E. (2006). Corruption in America. Journal of Public Economics, 90(6):1053-1072.

Goetz, A. M. (2007). Political cleaners: Women as the new anti-corruption force? Development and Change, 38(1):87-105.

Grove, W. A., Hussey, A., and Jetter, M. (2011). The gender pay gap beyond human capital: Heterogeneity in noncognitive skills and in labor market tastes. Journal of Human Resources, $46(4): 827-874$.

Gundlach, E. and Paldam, M. (2009). The transition of corruption: From poverty to honesty. Economics Letters, 103(3):146-148.

Islam, N. (1995). Growth empirics: A panel data approach. The Quarterly Journal of Economics, 110(4):1127-1170.

Jacoby, W. G. (2000). Loess: A nonparametric, graphical tool for depicting relationships between variables. Electoral Studies, 19(4):577-613.

Jetter, M., Montoya Agudelo, A., and Ramírez Hassan, A. (2015). The effect of democracy on corruption: Income is key. World Development, 74:286-304. 
Karim, S. (2011). Madame officer. Americas Quarterly, 5(3):42.

Kaufmann, D., Kraay, A., and Mastruzzi, M. (2011). The Worldwide Governance Indicators: Methodology and analytical issues. Hague Journal on the Rule of Law, 3(02):220-246.

Knack, S. and Azfar, O. (2003). Trade intensity, country size and corruption. Economics of Governance, 4(1):1-18.

Knack, S. F. and Azfar, O. (2000). Are larger countries really more corrupt?, volume 2470. World Bank Publications.

Krook, M. L. (2009). Quotas for women in politics: Gender and candidate selection reform worldwide. Oxford University Press, USA.

Masanjala, W. H. and Papageorgiou, C. (2008). Rough and lonely road to prosperity: A reexamination of the sources of growth in Africa using Bayesian model averaging. Journal of Applied Econometrics, 23(5):671-682.

Mocan, N. (2008). What determines corruption? International evidence from microdata. Economic Inquiry, 46(4):493-510.

Ram, R. (2009). Openness, country size, and government size: Additional evidence from a large cross-country panel. Journal of Public Economics, 93(1):213-218.

Rivas, M. F. (2013). An experiment on corruption and gender. Bulletin of Economic Research, 65(1):10-42.

Serra, D. (2006). Empirical determinants of corruption: A sensitivity analysis. Public Choice, 126(1-2):225-256.

Svensson, J. (2005). Eight questions about corruption. The Journal of Economic Perspectives, $19(3): 19-42$.

Swamy, A., Knack, S., Lee, Y., and Azfar, O. (2001). Gender and corruption. Journal of Development Economics, 64:25-55.

Treisman, D. (2000). The causes of corruption: A cross-national study. Journal of Public Economics, 76(3):399-457. 
Urra, F. J. (2007). Assessing corruption - an analytical review of corruption measurement and its problems: Perception, error and utility. Edmund A. Walsh School of Foreign Service (May), pages 1-20. 